УДК 629.058

DOI https://doi.org/10.32838/2663-5941/2020.4/34

Кухтик Н.О.

Національний транспортний університет

\title{
УТОЧНЕННЯ МАТЕМАТИЧНОЇ МОДЕЛІ РУХУ АВТОМОБІЛЯ З УРАХУВАННЯМ ПРОГРІВАННЯ ДВИГУНА В ПРОЦЕСІ РУХУ
}

Робота присвячена можливості математичного моделювання роботи легкового автомобіля у разі невизначеності умов експлуатації. Двигун автомобіля є споживачем палив нафтового походження $i$ джерелом викидів забруднюючих речовин у навколишнє середовище. Параметри середовища суттєво впливають на рівень викидів, особливо після запуску холодного двигуна та в період прогрівання двигуна. Зміна параметрів середовища найчастіше нехтується під час математичного моделювання складної технічної системи, якою є автомобіль з двигуном внутрішнього згорання.

У роботі представлена конщепџія моделі, яка включає можсливість врахування параметрів середовища для визначення рівня забруднення атмосферного повітря шкідливими викидами автомобільного двигуна.

Перехід від натуральних фізичних показників об'єктів моделювання до безрозмірних коефічієнтів дає змогу універсалізувати моделі і створити віртуальні об'єкти, які замінюють реальні об'єкти. При иьому всі ознаки реальних об'єктів забезпечуються модельованими системами.

Математична модель була розроблена на базі вже наявних моделей, щзо раніше були створені на кафедрі «Двигуни та теплотехніка» Національного транспортного університету.

Математична модель забезпечує імітацію руху автомобіля з бензиновим двигуном та системою нейтралізачії відпрацьованих газів за режимами міської частини Європейського їздового ииклу з урахуванням зміни температурного стану двигуна автомобіля в період прогрівання в русі.

Коефіцієнти впливу температурного стану двигуна на кінцеві експлуатачійні показники автомобіля з двигуном внутрішнього згоряння $і$ системою нейтралізаиї зі зворотним зв'язком розраховують за результатами експериментальних випробувань автомобіля за режимами Європейського їздового ииклу.

Ключові слова: математична модель, двигун, витрата палива, забруднюючі речовини, навколишнє середовище.

Постановка проблеми. Розрахункові методи досліджень у сучасних умовах виступають пріоритетними у зв'язку зі складністю, а іноді і неможливістю проведення великого обсягу натурних експериментів. Широке використання комп'ютерної техніки для моделювання фізичних об'єктів дає змогу більш точно дослідити проблему і встановити взаємозв' язок між більшим числом факторів, що впливають на результат. Тому створення якісної математичної моделі, що враховує досліджувану проблему, $\epsilon$ важливим науковим завданням.

Формулювання цілей статті. Ця стаття присвячена інформуванню наукової спільноти про один зі шляхів вирішення проблеми врахування зміни стану технічного об’єкта, зокрема температурного стану, у разі створення математичних моделей складних технічних систем.

Виклад основного матеріалу дослідження. Математична модель руху транспортного засобу імітує умовний рух у найбільш характерних режимах руху для типової експлуатації легкового автомобіля. Найбільше автомобілів зосереджено та експлуатується у великих містах, таких як Київ, Харків, Дніпро, Львів, Житомир та інші.

Режими руху автомобіля для великих міст ефективно відображає міська частина Європейського їздового циклу, яка відповідає Правилам ЄЕК ООН 83-05 [1].

Свропейський їздовий цикл складається 3 двох частин (рис. 1). Тривалість виконання циклу становить 1180 с. Перша частина - це міський їздовий цикл UDC (Urban Driving Cycle) 3 максимальною швидкістю руху 50 км/год, який включає чотири однакові послідовні фрагменти режимів зміни швидкості, що нагадує умови руху автомобіля по місту. Друга частина циклу - швидкісний заміський цикл EUDC (Extra Urban Driving Cycle) 3 максимальною швидкістю руху 120 км/год (або 90 км/год для автомобіля 3 меншою максимальною швидкістю), який відтворює умови руху автомобіля магістраллю.

Їздовий цикл повністю відтворює експлуатаційні умови: роботу двигуна автомобіля в режимі мінімальної частоти обертання активного холостого ходу та підвищеної частоти обертання холостого ходу перед початком руху, рух автомобіля 


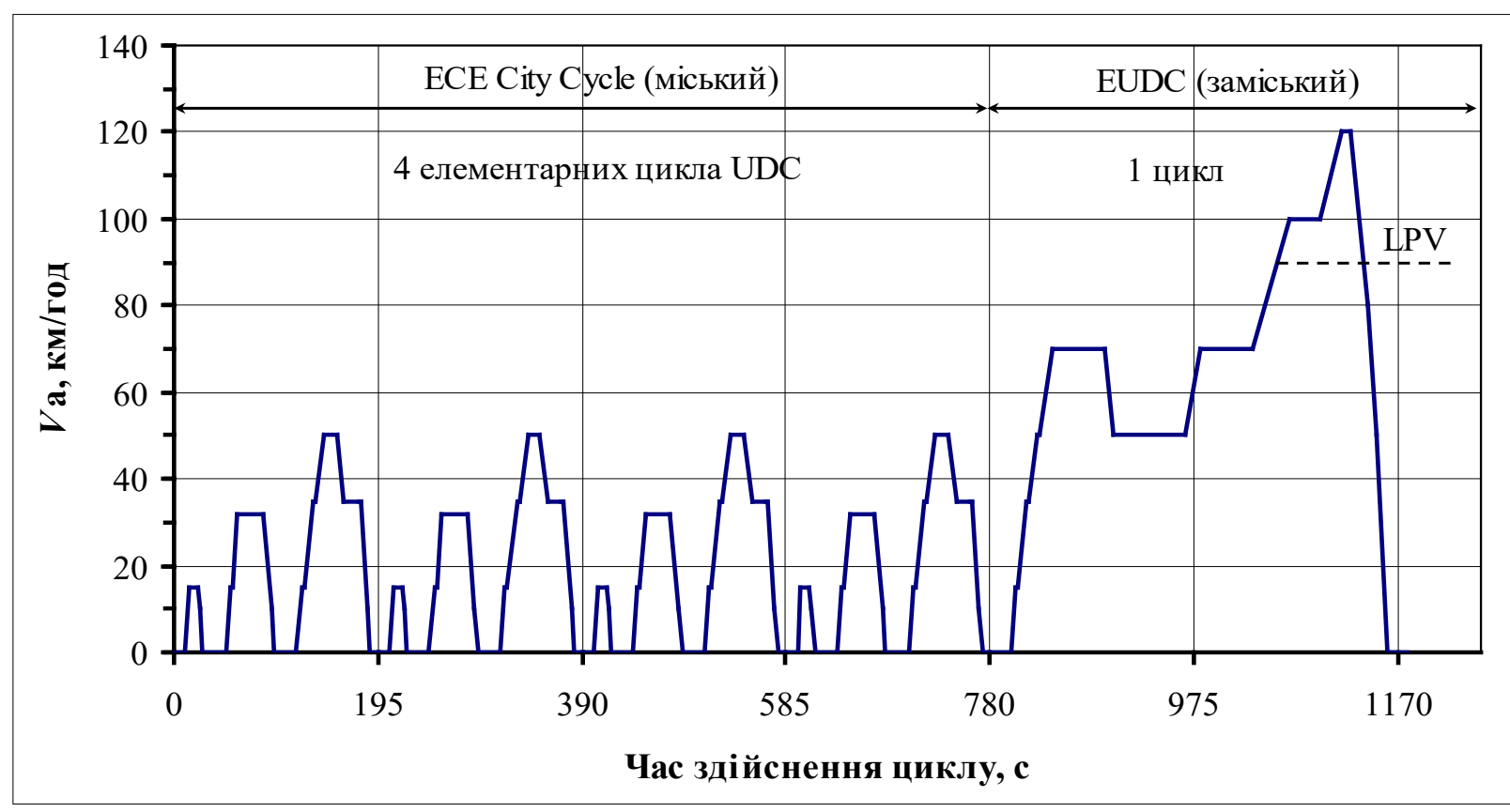

Рис. 1. Новий Європейський їздовий цикл (NEDC)

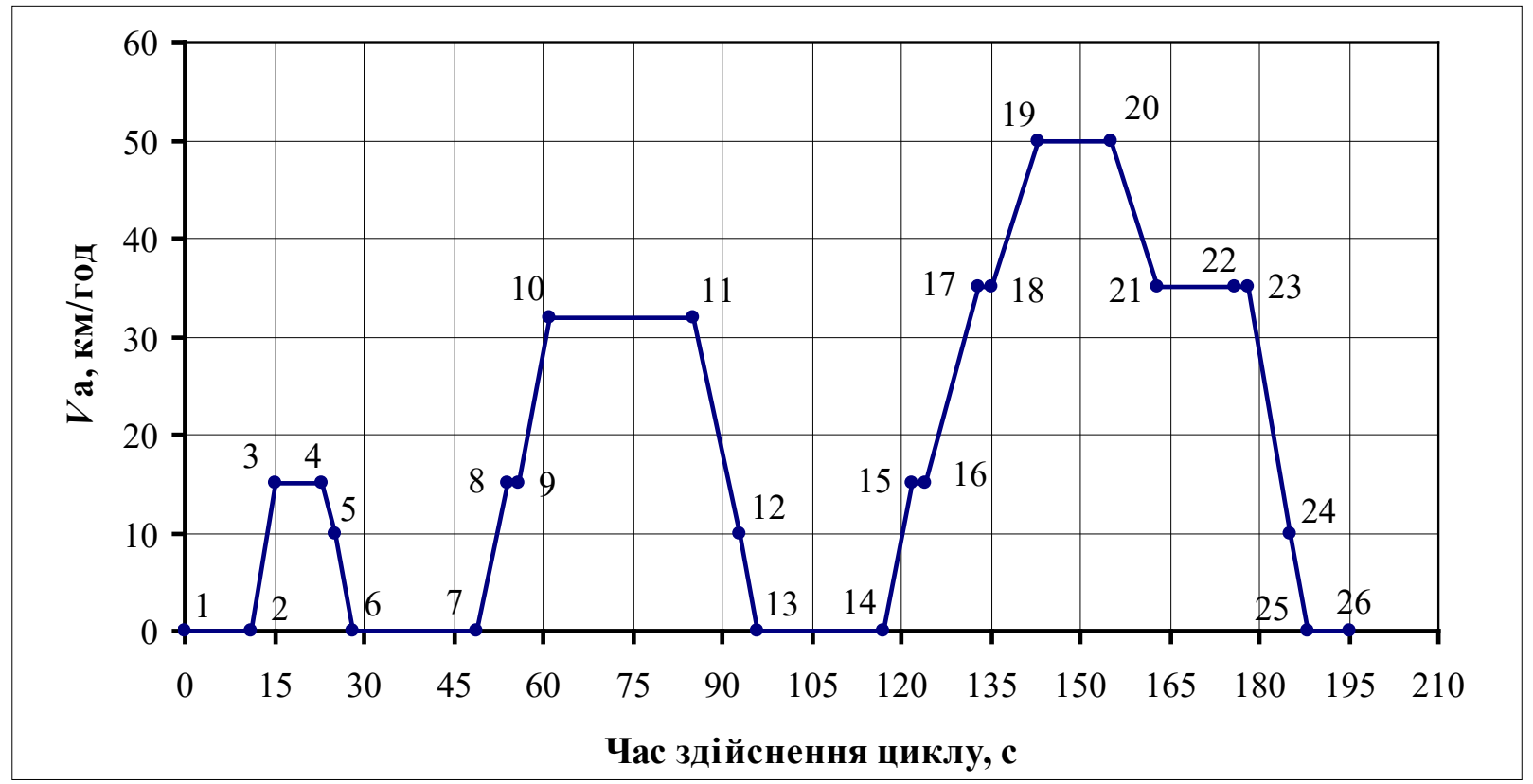

Рис. 2. Фрагмент міської частини Європейського їздового циклу

3 місця і розгін до певної швидкості, рух зі сталою швидкістю нетривалий час, перемикання передач з нижчої на вищу або у зворотному порядку, розгін автомобіля від однієї швидкості до іншої, гальмування двигуном для зменшення швидкості, службове гальмування до повної зупинки з використанням робочої гальмівної системи.

Оскільки чотири фрагменти міських режимів $\epsilon$ однаковими, розглянемо детально один фрагмент міських режимів руху автомобіля (рис. 2).
Математична модель базується на моделі, створеній на кафедрі «Двигуни та теплотехніка» Національного транспортного університету [2, с. 73]. Математичні залежності дають змогу розрахувати паливну економічність та викиди забруднюючих речовин у разі умовного руху автомобіля у відповідності до режимів Європейського їздового циклу на кожному з етапів проходження певного режиму і загалом за їздовий цикл. Модель характеризує систему, що об'єднує три підсистеми: 
автомобіль - дорога - водій. Для визначення впливу температури атмосферного повітря на експлуатаційні показники автомобіля та екологічне навантаження на середовище необхідно врахувати залежність рівня викидів забруднюючих речовин від температурного режиму двигуна та ввести до моделі додаткову підсистему - середовище.

Математична модель руху автомобіля - це система диференціальних рівнянь тягового балансу, якими встановлюються залежність зміни крутного моменту двигуна від умовної швидкості руху автомобіля або його прискорення чи сповільнення. Під час випробування автомобіля на стенді крутний момент двигуна визначається як сума моментів на подолання сил опору коченню на стенді з біговими барабанами, умовного опору повітря, а також сил інерції рухомих мас [3, с. 64].

За роботи двигуна автомобіля в режимі мінімальної частоти обертання холостого ходу на ділянках циклу 1-2, 6-7, 13-14, 25-26 (рис. 2) ефективний

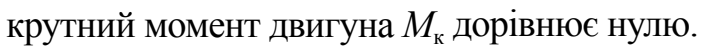

Показники двигуна, а саме годинну витрату палива, годинну витрату повітря, концентрації забруднюючих речовин, визначають як функції $f(n)$, де $n$ - частота обертання колінчастого валу. Залежно від температури $t_{0}$ атмосферного повітря витрата палива корегується коефіцієнтом температури $K_{\text {r }}$.

На інших ділянках фрагменту циклу двигун працює під навантаженням, яке визначається моментом опору руху автомобіля $M_{\text {оп }}$.

У визначенні режимів циклу приймається, що рух автомобіля здійснюється на рівній, горизонтальній ділянці дороги і рівняння тягового балансу може бути представлене у скороченому вигляді:

$$
M_{\text {оп }}=\frac{\left[\left(m_{0}+m_{\text {ван }}\right) \cdot f \cdot g+k F\left(\frac{V_{\mathrm{a}}}{3,6}\right)^{2}\right] \cdot r_{\text {д }}}{U_{i} \cdot U_{\text {гा }} \cdot \eta_{\mathrm{T}}},
$$

де $m_{0}$ - власна маса автомобіля, кг. Для автомобіля Hyundai Getz $m_{0}=1143$ кг [4, с. 153];

$V_{\text {а }}$ - швидкість руху автомобіля, км/год;

$m_{\text {ван }}$ - маса вантажу, кг. За умовами випробування легкових автомобілів за режимами Європейського їздового циклу $m_{\text {ван }}=100$ кг [5, с. 2];

$f$ - коефіцієнт опору коченню автомобіля;

$k F$ - фактор обтічності автомобіля, $\mathrm{H} \cdot \mathrm{c}^{2} / \mathrm{m}^{2}$;

$r_{\text {д }}-$ динамічний радіус колеса, м;

$g$ - прискорення вільного падіння, м/ $\mathrm{c}^{2}$;

$U_{i}, U_{\text {гा }}-$ передаточні числа коробки передач і головної передачі відповідно;

$\eta_{\mathrm{T}}-$ ККД трансмісії, $\eta_{\mathrm{T}}=0,88 \ldots 0,92$.
Крім цього, треба зазначити, що за руху з постійною швидкістю $M_{\text {оп }}-M_{\text {оп }}=0$, а за прискорення чи сповільнення:

$$
M_{\text {к }}-M_{\text {ог }}=\left(I_{\text {д }}+\frac{1}{\eta_{\text {т }}} \cdot I_{\text {пр }}\right) \cdot \frac{d \omega_{\text {д }}}{d t},
$$

де $I_{\text {д }}$ момент інерції двигуна, кг $* \mathrm{M}^{2}$;

$I_{\text {пр }}$ приведений до зчеплення момент інерції рухомих мас автомобіля, кГ* $\mathrm{M}^{2}$;

$\frac{d \omega_{\text {д}}}{d t}-$ кутове сповільнення колінчатого вала двигуна, $\mathrm{c}^{-2}$.

Паливна економічність та екологічні показники автомобіля найбільш повно характеризують транспортний засіб як споживача палива і джерело забруднення навколишнього середовища.

Масові викиди забруднюючих речовин розраховують за концентраціями цих речовин, годинними витратами палива $G_{\text {п }}$ (кг/год), значеннями коефіцієнта надміру повітря $\alpha$ та розрахованими числовими коефіцієнтами, наприклад:

$$
G_{C O}=\frac{28 \cdot C_{C O}}{100} \cdot(0,135713+0,33242 \cdot \alpha) \cdot G_{\text {п }} \text { при }
$$

$\alpha<1$.

Коефіцієнти впливу температурного стану двигуна на витрату палива і концентрації забруднюючих речовин (ЗР) у відпрацьованих газах (ВГ) розраховують за результатами експериментальних випробувань. Ці коефіцієнти являють собою відношення поточних витрат палива i концентрацій ЗР у процесі прогрівання двигуна до цих показників у разі випробування автомобіля з прогрітим двигуном залежно від температури охолодної рідини.

Коефіцієнти впливу температурного стану двигуна на витрату палива і концентрації ЗР у ВГ представляють у вигляді залежності від часу виконання їздового циклу та температури охолодної рідини. Поточну витрату палива і концентрації 3Р у ВГ у процесі прогрівання двигуна визначають як добуток коефіцієнтів впливу температурного стану двигуна на значення цих показників під час випробування автомобіля з прогрітим двигуном.

Для визначення впливу підігрівання повітря на впуску в двигун на паливну економічність і викиди ЗР автомобілем, виходячи 3 температури охолодної рідини на початку випробування i прийнявши закономірність іiі зміни такою ж як без підігрівання, розраховують відношення коефіцієнтів впливу температурного стану двигуна 3 підігрівом і без підігріву. Це відношення і визначає очікувану зміну показників роботи двигуна. Надалі визначають поточну витрату палива 
і концентрації ЗР у ВГ та витрату палива і викиди ЗР за процес прогрівання двигуна автомобіля до нормального теплового стану. Використовуючи отримані результати, можна досліджувати, як впливає тепловий режим двигуна на початку прогрівання на показники паливної економічності та екологічні показники автомобіля та вплив інших експлуатаційних факторів.

Одним з основних питань у оцінці впливу процесу прогрівання двигуна $є$ визначення впливу цього процесу на витрату палива.

Визначення температури охолодної рідини двигуна в процесі експериментального відтворення Європейського їздового циклу [6, с. 36] автомобілем 3 непрогрітим двигуном показало, що прогрів завершується за два фрагменти міської частини їздового циклу.

Але при цьому миттєва витрата палива (л/год) змінюється дуже інтенсивно і не дає змоги провести порівняння величин у режимах розгону і сповільнення. У зв'язку з цим для порівняння були застосовані більш статичні режими руху автомобіля зі сталими швидкостями: 15,32 і 50 км/год і робота двигуна в режимі мінімальної частоти обертання холостого ходу. Ці заміри найбільш достовірні.

Заміряні величини годинної витрати палива $\left(V_{\text {п }}\right.$ л/год) у разі швидкостей 15,32 і 50 км/год у різних фрагментах міської частини циклу показані на рис. 3.

Як видно 3 показаних залежностей, годинна витрата палива у разі всіх швидкостей руху по мірі прогрівання двигуна зменшується, але характер змінювання дещо відрізняється.

У процесі прогрівання двигуна змінюється годинна витрата бензину за роботи двигуна в режимі мінімальної частоти обертання холостого ходу (рис. 4). Як видно 3 наведених даних, по мірі прогріву годинна витрата палива $V_{\square}$ зменшується.

Оскільки тепловий стан двигуна можна оцінити температурою охолодної рідини, доцільно визначити залежність цієї температури від часу проходження автомобілем циклу з використанням надалі залежності витрати бензину від температури і розрахунку коефіцієнтів впливу температурного стану. Залежність температури охолодної рідини від часу проходження автомобілем циклу, отримана в експерименті, показана на рис. 5.

Всі показані залежності описані поліномами, приведеними на рисунках. Ці поліноми можна використати в розрахункових дослідженнях.

Висновки. Уточнено математичну модель руху автомобіля Hyundai Getz за режимами Нового Європейського їздового циклу. Визначено основні залежності для визначення паливної
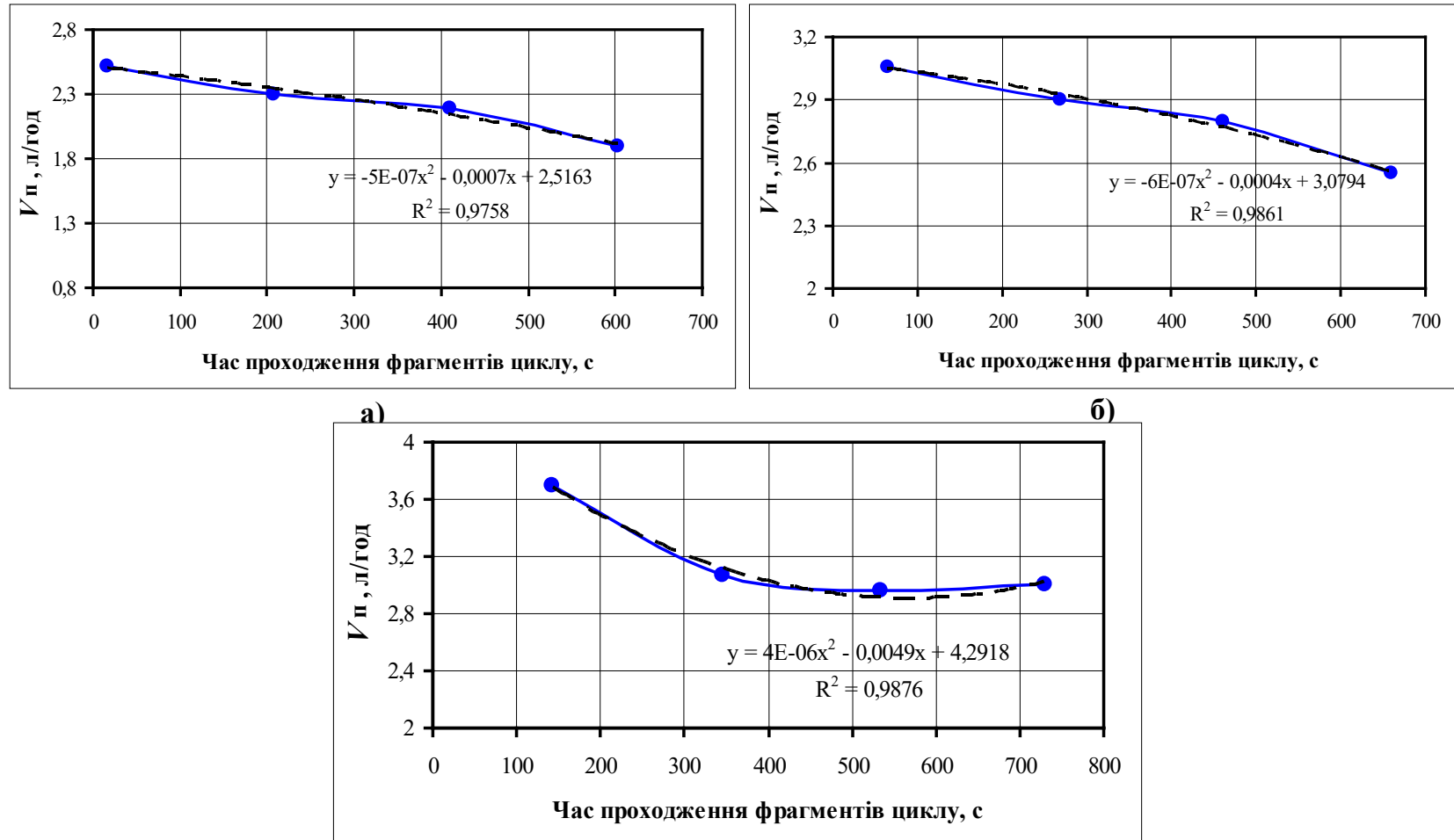

B)

Рис. 3. Зміна годинної витрати палива у разі сталої швидкості руху автомобіля: а) у разі 15 км/год; б) у разі 32 км/год; в) у разі 50 км/год 


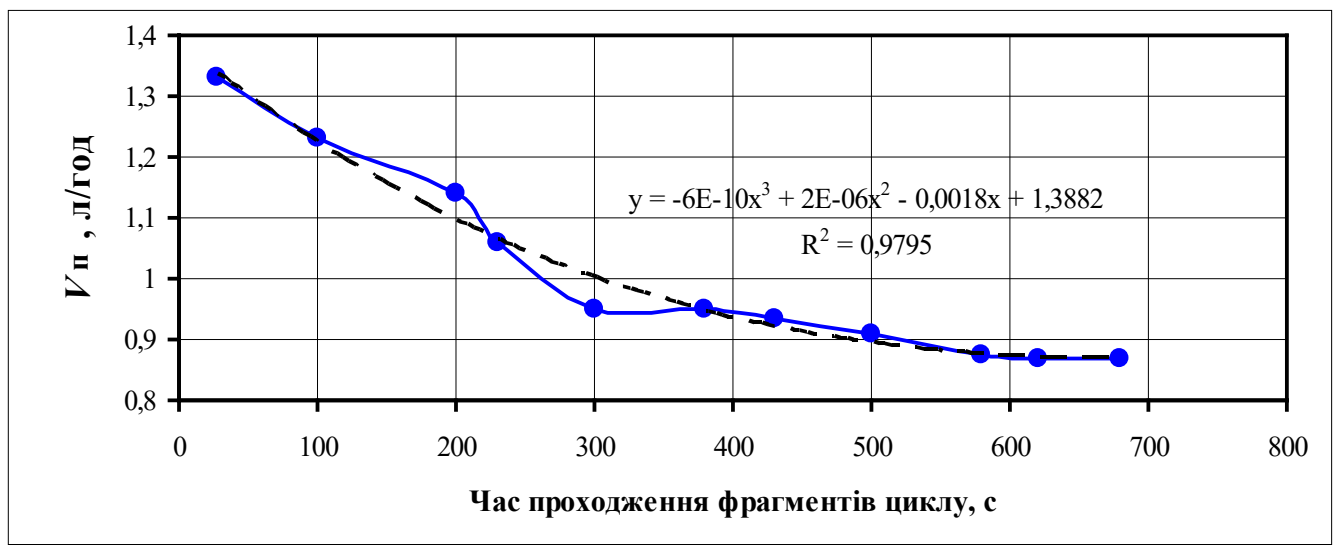

Рис. 4. Зміна витрати палива під час роботи двигуна в режимі холостого ходу за фрагментами міського їздового циклу

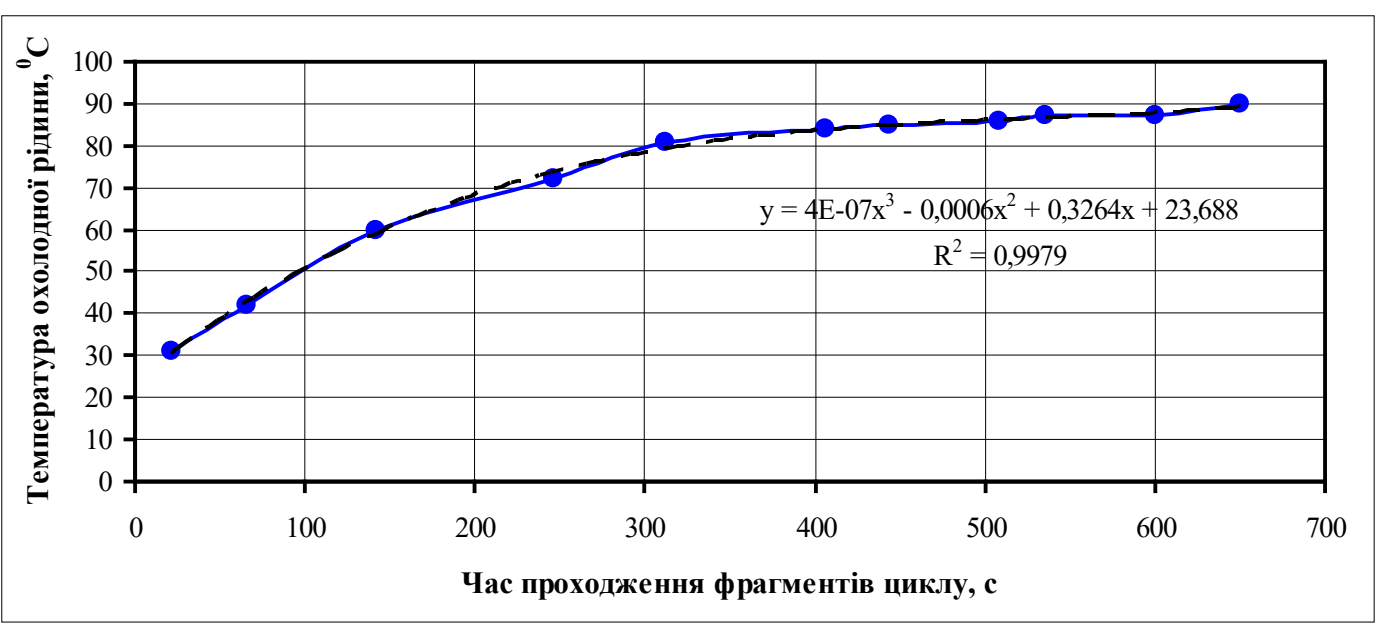

Рис. 5. Зміна температури охолодної рідини у разі проходження міської частини циклу з непрогрітим двигуном

економічності та екологічних показників автомобіля в процесі руху за їздовим циклом. Запропоновано методику врахування температурного стану двигуна автомобіля в математичній моделі. Експериментально встановлені залеж- ності витрати палива в період прогріву двигуна, які дають змогу встановити коефіцієнти температурного впливу на витрату палива за умовного руху автомобіля міською частиною Європейського їздового циклу.

\section{Список літератури:}

1. Єдині технічні приписи щодо офіційного затвердження колісних транспортних засобів стосовно викидів забруднювальних речовин залежно від палива, необхідного для двигунів (Правила ЕЭК ООН № 83-05:2005, IDT): ДСТУ UN/ECE R 83-05:09. (Чинний від 2009-10-01). Київ : Держспоживстандарт України, 2009. 343 с. (Національні стандарти України).

2. Гутаревич Ю. Снижение вредных выбросов и расхода топлива двигателями автомобилей путем оптимизации эксплуатационных факторов : дис. ... д-ра техн. наук : 05.22.10, 05.04.02. Киев, 1985. 538 с.

3. Кульбако В.П. Покращення екологічних показників автомобіля в експлуатаційних умовах добавкою біоетанолу до бензину : дис ... канд. техн. наук : 05.22.20. Київ, 2012. 212 с.

4. Кухтик Н.О. Вплив методу прогріву на витрату палива автомобілем з двигуном із системою впорскування бензину. / Кухтик Н.О., Кухтик В.В. Міжвузівський збірник «Наукові нотатки» (за галузями знань «Технічні науки»). Луцьк, 2018. Випуск 62. С. 152-156.

5. Автотранспортные средства. Топливная экономичность. Методы испытаний: ГОСТ 20306-90. (Чинний від 1992-01-01). Москва : Изд-во стандартов, 1991. 32 с. (Національний стандарт України). 
6. Кухтик Н. Порівняння витрати палива та викидів шкідливих речовин непрогрітого та прогрітого двигуна легкового автомобіля за Європейським їздовим циклом. Systemy i środki tranaportu samochodowego. Badania i technologia silników spalinowych. Wybrane zagadnienia. Monografia. Nr 17. Seria: Transport. Rzezów. 2019. Pp. 35-41.

\section{Kukhtyk N.O. SPECIFICATION OF THE MATHEMATICAL MODEL OF THE VEHICLE MOVEMENT TAKING INTO ACCOUNT HEATING OF THE ENGINE IN THE PROCESS OF MOVEMENT}

The work is devoted to the possibility of mathematical modeling of the car work in case of uncertainty of operating conditions. The car's engine is a consumer of petroleum fuels and a source of pollutant emissions into the environment. Environmental parameters significantly affect the level of emissions, especially after starting the cold engine and during the engine warm-up period. Changing the parameters of the environment is often neglected in the mathematical modeling of a complex technical system, which is a car with an internal combustion engine.

The work presents the concept of the model, which includes the ability to take into account the parameters of the environment at determining the level of air pollution by harmful emissions from the car engine.

The transition from natural physical parameters of modeling objects to dimensionless coefficients allows to universalize models and create virtual objects which replace real objects. In this case, all features of real objects are provided by simulated systems.

The mathematical model was developed on the basis of existing models that were previously created at the Department of Engines and Heating Engineering of the National Transport University.

The mathematical model provides simulation of the movement of a car with a gasoline engine and a neutralization system of exhaust gases according to the modes of the urban part of the European driving cycle, taking into account changes in temperature of the car engine during warm-up.

The coefficients of influence of the engine temperature state on the final performance indicators of a car with an internal combustion engine and a feedback neutralization system are calculated based on the results of experimental tests of the car according to the modes of the European driving cycle.

Key words: mathematical model, engine, fuel consumption, pollutants, environment. 